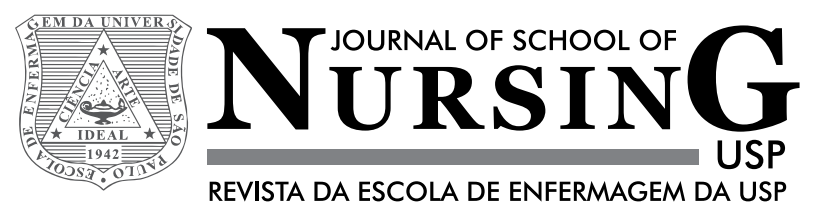

\title{
Prevalence of self-reported constipation in adults from the general population
}

\author{
Prevalência de constipação intestinal autorreferida em adultos da população geral \\ Prevalencia de constipación autorreferido en adultos de la población general
}

Fernanda Mateus Queiroz Schmidt ${ }^{1}$, Vera Lúcia Conceição de Gouveia Santos ${ }^{2}$, Rita de Cássia Domansky ${ }^{3}$, Elaine Barros ${ }^{4}$, Mariana Alves Bandeira ${ }^{5}$, Mariana Alves de Melo Tenório ${ }^{6}$, José Marcio Neves Jorge ${ }^{7}$

${ }^{1}$ WOC nurse, Santa Casa de Misericórdia de Passos - Regional Cancer Hospital, Passos, MG, Brazil.

${ }^{2}$ Associate Professor, Department of MedicalSurgical Nursing, School of Nursing, University of Sao Paulo, Sao Paulo, SP, Brazil.

${ }^{3} \mathrm{PhD}$ in Sciences, School of Nursing, University of Sao Paulo, Sao Paulo, SP, Brazil.

${ }^{4}$ Nurse of the Servidor Público Estadual Hospital - HSPE, Sao Paulo, SP, Brazil.

${ }^{5}$ Technical Consulting Nurse of Smith \& Nephew, Sao Paulo, SP, Brazil.

${ }^{6}$ Oncologist nurse, Onofre Lopes Teaching Hospital, University of Rio Grande do Norte, Natal, RN, Brazil.

${ }^{7}$ Associate Professor, Departament of Gastroenterology, School of Medicine, University of Sao Paulo, Sao Paulo, SP, Brazil.

\begin{abstract}
Objective: To estimate the prevalence of self-reported constipation and associated factors in the general population of a Brazilian city. Method: Secondary analysis of an epidemiological study, population-based, cross-sectional study, about bowel habits of Brazilian population. A total of 2,162 individuals were interviewed using two instruments: sociodemographic data and the adapted and validated Brazilian version of the "Bowel Function in the Community" tool. Results: There was a prevalence of $25.2 \%$ for the selfreported constipation, $37.2 \%$ among women and $10.2 \%$ among men. Stroke and old age were associated with constipation in the three statistical models used. Conclusion: The prevalence found showed to be similar to the findings in the literature, although some associated factors obtained here have never been investigated.
\end{abstract}

\section{DESCRIPTORS}

Constipation; Prevalence; Epidemiology; Nursing; Cross-Sectional Studies. 


\section{INTRODUCTION}

Chronic Constipation (CC) is a syndrome based on symptoms defined as unsatisfactory defecation that results from difficult stool passage or infrequent stools, hard stools, or feeling of incomplete defecation, which can occur individually or secondarily to an underlying disease ${ }^{(1)}$. According to self-reported, it is characterized by subjective complaint influenced by cultural habits ${ }^{(2)}$. According to the Rome III criteria $^{(3)}, \mathrm{CC}$ is defined as the presence of two or more of the following symptoms for the last three months, with onset at least 6 months before diagnosis: straining during at least $25 \%$ of defecations, lumpy or hard stools in at least $25 \%$ of defecations, sensation of incomplete evacuation for at least $25 \%$ of defecations, sensation of anorectal obstruction/blockage for at least $25 \%$ of defecations, manual maneuvers to facilitate at least $25 \%$ of defecations (e.g., digital evacuation and support of the pelvic floor), and lesser than three defecations per week. In addition to these, two more symptoms of constipation are considered: stools that occur rarely without the use of laxatives, and non-fulfillment of the criteria for irritable bowel syndrome.

CC prevalence ranges between $2.6 \%$ and $30.7 \%$, as indicated by some studies ${ }^{(4-8)}$, highlighting the female and old age as associated factors ${ }^{(4)}$.

In order to provide recommendations for assessment, diagnosis and treatment of $\mathrm{CC}$, and from a systematic review of literature conducted by experts from across the region, the Latin American Consensus of Chronic Constipation was published in November 2005, which points out that there are few epidemiological studies on the subject in Latin America ${ }^{(6)}$.

A complete history, including surgery, diet and medications taken, is part of the evaluation of patients with $\mathrm{CC}$ performed by nurses ${ }^{(9)}$. Proper understanding of the symptoms of functional gastrointestinal disorders (FGIDs) or not, is needed by health professionals to recognize the impact on patients and a rational basis for knowing diagnose and treat them ${ }^{(10)}$.

It is necessary to consider that $\mathrm{CC}$ can cause serious complications such as fecaloma, pseudo-diarrhea, stercoral ulcer, volvulus and gastrointestinal perforation, especially in patients with megacolon and megarectum. Therefore, recognition of the symptom and an early treatment are necessary to prevent complications and improve the quality of life of patients $^{(11)}$ Moreover, within the specialized area of Wound, Ostomy and Continence Nursing (WOCN), incontinence include constipation as one of its sub-areas of expertise. The care of people with constipation - which can occur in any health care setting, particularly in hospitals and long-term institutions and in the end of life - it is relevant for Nursing area, specialized or not.

Given the above and considering the lack of epidemiological studies in Latin America, specifically in Brazil, the aim of this study is to estimate the prevalence of selfreported CC and identify the factors associated with this occurrence in adults from the general population.

\section{METHOD}

This is a secondary analysis, developed from an epidemiological population-based, descriptive, exploratory and cross-sectional study, with quantitative approach, conducted between 2008 and 2009 in the urban area of Londrina - Parana, on the bowel habits of this population $^{(12)}$. At the time of data collection, the city had a population of 447,065 inhabitants, of which 305,695 individuals were over 18 years old, according to the census of the Brazilian Institute of Geography and Statistics - IBGE 2000. The study population was composed by all inhabitants residing in the urban area of this city, divided into 390 census sectors, grouped into five regions (north, south, east, west and center). The population was stratified by gender and age. The study sample consisted of all residents present in households, selected through cluster probabilistic sampling and who met the following inclusion criteria: age equal or above 18 years old, to be able to respond to interview questions and to accept to participate in the study. As we had access to the city map, containing all addresses and 390 census sectors according to IBGE; information on the general population by census sectors; and the number of elements in each region, depending on the age and gender, the calculation of the sample obtained consisted of 2,000 inhabitants. Then, the selection of clusters was performed through a draft, being first drawn the census sectors of each region, followed by the draw for the street to be visited, that is the cluster. Finally, the sample consisted of 2,162 individuals, most were women (1203 - 56\%); white (1591 - 73.6\%); people in stable relationships (59.7\% - 1290); literate $(97.5 \%-2108)$, with 0 to 33 years of education (mean 9.4, $\mathrm{SD}=4.5$ years); 809 (37.4\%) participants had no defined occupation. The age ranged from 18 to 93 years (mean $40.6, \mathrm{SD}=16.4$ years); the mean monthly family income of participants was $3.8(\mathrm{SD}=3.3)$ minimum wages ${ }^{\text {a }}$, and the number of dependents monthly household income ranged from 1 to 13 people (mean 3.1, $\mathrm{SD}=1.4)$.

The research project of the primary study was approved by the Research Ethics Committee of the School of Nursing of the Universidade de Sao Paulo (No. 485/2005/ CEPEEUSP) and received financial support from the Sao Paulo Research Foundation (FAPESP), process 2006/50006-1.

Data collection was conducted from April to May 2008, by ten undergraduate Nursing students from the Universidade Estadual de Londrina - UEL, they were previously submitted to a process of training involving the objectives and procedures of the study, with emphasis on data collection, through the interview technique. During data collection, all residents occupants of households were interviewed. Study participants were informed about the research objectives, expressing their consent to participate by signing the consent form.

${ }^{\text {a }}$ The minimum wage per month in Brazil corresponds to $\mathrm{R} \$ 788,00$ reais or U\$ 260,06 dollars according to the Central Bank of Brazil on March $7^{\text {th }}, 2015$ 
Two instruments were used for data collection. The first consisted of the subjects' demographic data (name, age and date of birth, gender, skin color, education, profession and occupation, marital status, monthly family income and number of dependents of this income). The second instrument, Bowel Function in the Community, in its adapted and validated version to Brazil ${ }^{(13)}$, intended to assess the sample's bowel function. This instrument contains 68 questions, of which 67 are multiple choice (2 to 9 response alternatives). The latest question included 17 general symptoms unrelated to bowel habits. Although the instrument has no scores, each response alternative receives a score ranging from 0 to 9 . The questions are divided into: general bowel habits; fecal incontinence; urinary symptoms; anal-rectal diseases and surgical history; medical care utilization and potential contributing medical disorders. Considering that the present study aimed to determine the prevalence of $\mathrm{CC}$ (question 14) and its associated factors, we used the items contained in the clusters general bowel habits, anal-rectal diseases and surgical history (questions 46 to 50 and 53 to 59 ).

The data from both instruments were analyzed using the software R 3.1.1, R Core Team (2013).

The prevalence of $\mathrm{CC}$ was assessed by self-report, considering constipated people who responded 1 (I had constipation often, more than $25 \%$ of the time) or responded 2 (I sometimes had constipation, less than $25 \%$ of the time), and question number 14 of the specific instrument, which deals with how regular or how often the person evacuated last year.

For the study of associated factors (independent variables), the data were subjected to univariate analysis using the Pearson chi-square test $\left(\mathrm{X}^{2}\right)$, with $5 \%$ significance level. For the univariate analysis, we presented as measures of effect, the crude odds ratio (OR). A multivariate logistic regression was held to further elucidate these relationships and analyze the effect of each variable adjusted for the effect of the other. Final associations were measured by adjusted Odds Ratio (ORadj), with respective $95 \%$ confidence intervals (95\% CI). Three models of multivariate analysis were developed to establish the relationship between demographic and clinical variables and of all significant variables: a general model, with all constipated individuals and two models stratified by gender. In the general model, the following variables were tested: radiotherapy, abscess or infection, fistula, anal fissure, surgery in the rectum or anus, stroke, rectal prolapse, hemorrhoids, trauma or wound around the anus, diabetes mellitus, reduced or pushed hemorrhoids and nervous system disorders. In the model for women, we also included: women delivery history, presence of injury or laceration of the anus during delivery and antecedent or rectocele hysterectomy, in addition to the other variables also included in the other two models. The $\mathrm{p}$ value was set at $5 \%$.

The quality and the discriminating power of the adjusted models were analyzed using the Receiver Operating Characteristic curve (ROC) ${ }^{(14)}$ for each of the three models.
The ROC curve measures the accuracy of the estimated probabilities to predict CC.

\section{RESULTS}

Of the 2,162 participants, 546 were considered constipated according to self-reported; $340(62.3 \% / 15.7 \%)$ of whom had already had CC frequently and 206 (37.7\% / 9.5\%) sometimes.

The estimated prevalence of CC was $25.2 \%$ (CI 23.4\% - 27.1\%), with $37.2 \%$ for women and $10.2 \%$ among men.

Figure 1 shows that $\mathrm{CC}$ increases with age in both males and for the entire sample, from 60 years. For all groups, CC shows the highest prevalence among the oldest participants (75 to 100 years old).

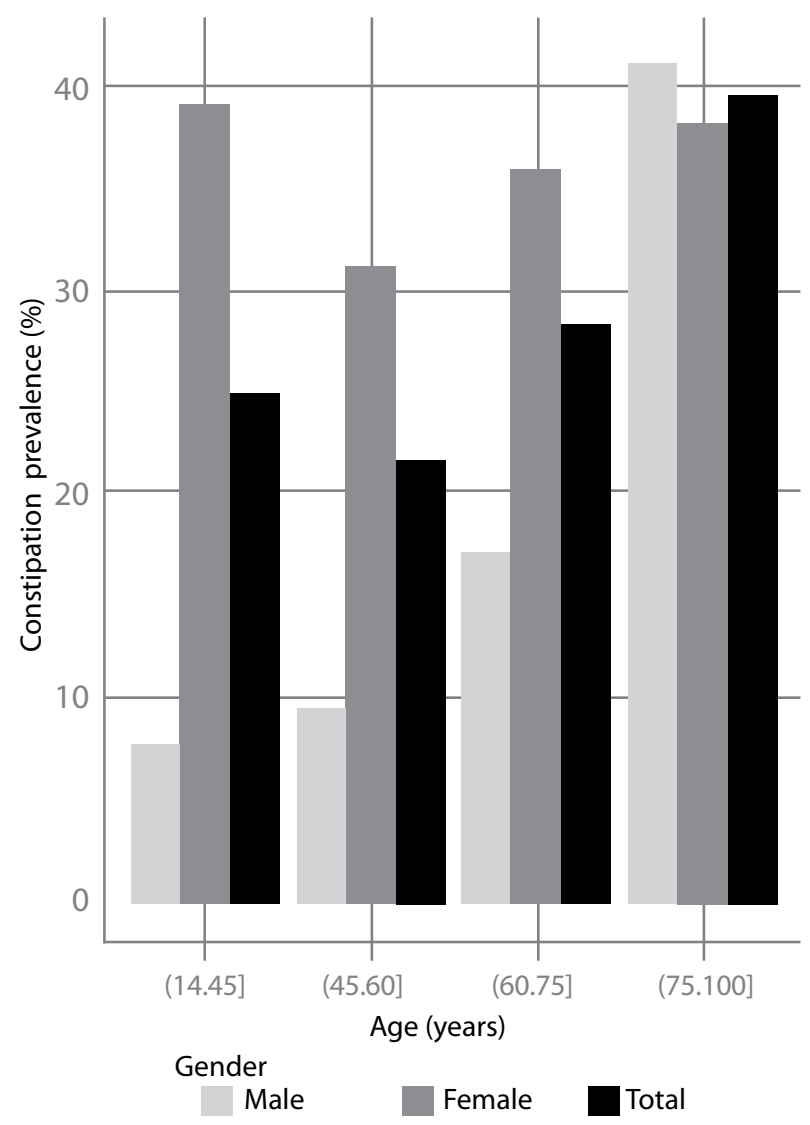

Figure 1 - CC prevalence according to age and gender - Londrina, PR, Brazil, 2008.

Among the demographic variables associated with CC, Table 1 highlights that women are 4.8 (95\% CI 3.8 - 6.2) more likely to mention constipation when compared to men; individuals between 75 and 100 years are 1.8 (95\% CI 1.0 - 3.2) more likely to have CC when compared to the younger ages. For clinical factors, it highlights the presence of fistula $(\mathrm{OR}=2.9 / 95 \% \mathrm{CI} 1.1-7.9)$; anal fissure $(\mathrm{OR}=$ 1.8 / 95\% CI $1.1-3.0)$; rectum or anus surgery $(\mathrm{OR}=2.2$ / 95\% CI $1.2-6.0)$; trauma or wound around the anus (OR $=2.6 / 95 \%$ CI 1.2 - 6.0); hemorrhoids $(\mathrm{OR}=1.9 / 95 \%$ CI 1.4 - 2.6); nervous system disorders $(\mathrm{OR}=1.6 / 95 \% \mathrm{CI}$ 1.2 - 2.0); and stroke (OR = 3.9 / 95\% CI 1.7 - 9.6). 
Table 1 - Unadjusted and adjusted odds Ratio (OR) with $95 \%$ CI for the association between self-reported CC and sociodemographic and clinical variables - Londrina, PR, Brazil, 2008.

\begin{tabular}{|c|c|c|c|c|c|c|}
\hline \multirow{4}{*}{ Variable } & \multicolumn{3}{|c|}{ Unadjusted OR } & \multicolumn{3}{|c|}{ Adjusted OR } \\
\hline & \multirow{2}{*}{ OR } & \multicolumn{2}{|c|}{ IC $(95 \%)$} & \multirow{2}{*}{ OR } & \multicolumn{2}{|c|}{ IC $(95 \%)$} \\
\hline & & Lower Limit & Upper Limit & & Lower Limit & Upper Limit \\
\hline & \multicolumn{6}{|c|}{ Sociodemographic variables } \\
\hline \multicolumn{7}{|l|}{ Ethnicity } \\
\hline White & 1.0 & & & 1,0 & - & - \\
\hline Yellow & 0.3 & 0,1 & 0,8 & 0,2 & 0,0 & 0,7 \\
\hline Brown & 0.9 & 0,6 & 1,2 & 1,0 & 0,7 & 1,4 \\
\hline Black & 1.0 & 0,6 & 1,4 & 1,1 & 0,7 & 1,7 \\
\hline Other & 1.0 & 0,6 & 1,4 & 1,2 & 0,8 & 1,8 \\
\hline \multicolumn{7}{|l|}{ Literacy } \\
\hline No & 1.0 & & & \multirow{2}{*}{\multicolumn{3}{|c|}{ NS }} \\
\hline Yes & 0.7 & 0,4 & 1,4 & & & \\
\hline \multicolumn{7}{|l|}{ Gender } \\
\hline Male & 1.0 & & & 1,0 & - & - \\
\hline Female & 5.2 & 4,1 & 6,6 & 4,8 & 3,7 & 6,1 \\
\hline \multicolumn{7}{|l|}{ Education } \\
\hline Illiterate & 1.0 & & & & & \\
\hline Literate & 0.9 & 0,5 & 1,7 & & & \\
\hline Primary school completed & 0.8 & 0,4 & 1,5 & & NS & \\
\hline Secondary school completed & 0.7 & 0,3 & 1,2 & & & \\
\hline Higher education & 0.6 & 0,3 & 1,3 & & & \\
\hline \multicolumn{7}{|l|}{ Occupation } \\
\hline Level 0 & 1.0 & & & & & \\
\hline Level 1 & 0.7 & 0,4 & 1,0 & & & \\
\hline Level 2 & 0.6 & 0,4 & 0,7 & & NS & \\
\hline Level 3 & 0.6 & 0,5 & 0,9 & & & \\
\hline Level 4 & 0.5 & 0,3 & 0,7 & & & \\
\hline Level 5 & 0.6 & 0,4 & 0,8 & & & \\
\hline \multicolumn{7}{|l|}{ Marital status } \\
\hline Single & 1.0 & & & & & \\
\hline Separated/Divorced & 1.2 & 0,8 & 1,8 & & & \\
\hline Stable union & 1.3 & 1,0 & 1,6 & & NS & \\
\hline Widow(er) & 1.8 & 1,2 & 2,7 & & & \\
\hline \multicolumn{7}{|l|}{ Age } \\
\hline$(14,45]$ & 1.0 & & & 1,0 & - & - \\
\hline$(45,60]$ & 0.8 & 0,6 & 1,0 & 0,6 & 0,5 & 0,8 \\
\hline$(60,75]$ & 1.1 & 0,8 & 1,6 & 0,9 & 0,6 & 1,3 \\
\hline$(75,100]$ & 1.9 & 1,1 & 3,2 & 1,8 & 1,0 & 3,2 \\
\hline \multicolumn{7}{|l|}{ Income in minimum wages ${ }^{1}$} \\
\hline$(2,15]$ & 1.0 & & & & & \\
\hline$(1,5,2]$ & 0.8 & 0,6 & 1,3 & & & \\
\hline$(1,1,5]$ & 0.8 & 0,6 & 1,2 & & NS & \\
\hline$(0,5,1]$ & 0.9 & 0,7 & 1,3 & & & \\
\hline$(0,0,5]$ & 1.4 & 1,0 & 2,0 & & & \\
\hline
\end{tabular}


Variable

\begin{tabular}{lllll}
\multicolumn{2}{c}{ Unadjusted OR } & \multicolumn{2}{c}{ Adjusted OR } \\
\hline \multirow{2}{*}{ OR } & \multicolumn{2}{c}{ IC $(95 \%)$} & & \multicolumn{2}{c}{ IC $(95 \%)$} \\
\cline { 2 - 2 } OR & Lower Limit & Upper Limit & & Lower Limit Upper Limit \\
\hline \multicolumn{2}{c}{ Clinical variables } & &
\end{tabular}

\section{Abscess/infection}

No

Yes

\section{Fistula}

No

Yes

\section{Anal fissure}

No

Yes

Yes

Trauma and injury in the rectum or anus

No

Yes

No

Hemorrhoids

No

Yes

Reduced/pushed the hemorrhoids

No, it came back on its own

1,0

Yes, I pushed it

No, it has always been out

\section{Radiotherapy}

No

Yes

Diabetes Mellitus

No

1,0

Yes

Nervous system disorder

No

1,0

Yes

2,0

1,5

2,6

1,0

\section{Stroke}

No

Yes

1,0

4,2

2,0

9,0

3,9

1,6

9,6

$\mathrm{NS}=$ Not significant

$\mathrm{R}^{2}=0.020 ; \mathrm{C}=0.743$.

${ }^{8}$ The minimum wage per month in Brazil corresponds to $\mathrm{R} \$ 788,00$ reais or U\$ 255,18 dollars according to the Central Bank of Brazil on April 14th, 2015. 
Table 2 shows that the black ethnicity $(\mathrm{OR}=1.3 /$ $95 \%$ CI $0.8-2.1)$ and the age group between 75 and 100 years $(\mathrm{OR}=0.8 / 95 \% \mathrm{CI} 0.4-15)$ highlight the demographic factors associated with $\mathrm{CC}$ among women and the age group between 75 and 100 years $(\mathrm{OR}=7.6 / 95 \% \mathrm{CI}$ 3.3 - 17.0) among men. Concerning to clinical variables, only stroke remained showing statistically significant association for both genders. Anal fissure, anal or rectum surgery, trauma or wound around the anus, rectocele and hemorrhoids stand out among women and for men, nervous system disorder and stroke. The variables age and stroke were repeated in the three models.

Table 2 - Unadjusted and adjusted odds Ratio (OR) with 95\% Cl for associations between the presence of CC and the sociodemographic and clinical variables according to gender - Londrina, PR, Brazil, 2008.

\begin{tabular}{|c|c|c|c|c|c|c|c|c|c|c|c|c|}
\hline \multirow{4}{*}{ Variable } & \multicolumn{6}{|c|}{ Female } & \multicolumn{6}{|c|}{ Male } \\
\hline & \multicolumn{3}{|c|}{ Adjusted OR } & \multicolumn{3}{|c|}{ Unadjusted OR } & \multicolumn{3}{|c|}{ Adjusted OR } & \multicolumn{3}{|c|}{ Unadjusted OR } \\
\hline & \multirow{2}{*}{ OR } & \multicolumn{2}{|c|}{$95 \% \mathrm{Cl}$} & \multirow{2}{*}{ OR } & \multicolumn{2}{|c|}{$95 \% \mathrm{Cl}$} & \multirow{2}{*}{ OR } & \multicolumn{2}{|c|}{$95 \% \mathrm{Cl}$} & \multirow{2}{*}{ OR } & \multicolumn{2}{|c|}{$95 \% \mathrm{Cl}$} \\
\hline & & Low & Up & & Low & Up & & Low & Up & & Low & Up \\
\hline
\end{tabular}

\section{Ethnicity}

Yellow

Brown

Black

Other

1.0

$0.2 \quad 0.0$

$0.9 \quad 0.6$

$1,2 \quad 0,7$

$1,2 \quad 0,7$

Literacy

No

Yes

Education

Illiterate

Literate

Primary school completed

Secondary school completed

Higher education

\section{Occupation}

Level 0

Level 1

Level 2

Level 3

Level 4

Level 5

Marital status

Single

Separated/Divorced

Stable union

Widow(er)

Age groups

$(14,45]$

$(45,60]$

$(60,75]$

$(75,100]$
1,0

$1,4 \quad 0,6 \quad 2,8 \quad$ NS

1.0

$\begin{array}{ll}1.6 & 0.7\end{array}$

3.3

$\begin{array}{ll}1.6 & 0.7\end{array}$

3.4

$1.3 \quad 0.6$

2.8

$1.1 \quad 0.5$

2.5

NS

1.0

$\begin{array}{ll}1.1 & 0.7\end{array}$

1.7

$\begin{array}{ll}1.2 & 0.9\end{array}$

1.7

$\begin{array}{ll}1.1 & 0.7\end{array}$

1.6

$1.1 \quad 0.6$

1.9

$0.7 \quad 0.5$

$1.1 \quad$ NS

1.0

$0.8 \quad 0.4$

1.3

1.20 .9

1.6

$0.9 \quad 0.6$

1.5 NS

$\begin{array}{ll}1.0 & 1.0\end{array}$

$\begin{array}{llll}0.7 & 0.5 & 0.9 & 0.6\end{array}$

$0.8 \quad 0.6$

$\begin{array}{ll}1.2 & 0.8\end{array}$

$0.9 \quad 0.5$
1.0

$0.0 \quad 0.6$

$0.6 \quad 1.5$

$0,8 \quad 2,0$

$0,8 \quad 2,2$

S

$0,2 \quad 0,0 \quad 0,7 \quad$ NS

1.0

$\begin{array}{lll}0.3 & 0.1 & 0.9\end{array}$

$\begin{array}{lll}0.2 & 0.0 & 0.7\end{array}$

$0.2 \quad 0.0 \quad 0.6$

$\begin{array}{llll}0.2 & 0.0 & 0.8 & \text { NS }\end{array}$

1.0

$\begin{array}{lll}0.3 & 0.1 & 0.9\end{array}$

$\begin{array}{lll}0.3 & 0.2 \quad 0.6\end{array}$

$\begin{array}{lll}0.4 & 0.2 & 0.8\end{array}$

$\begin{array}{lll}0.4 & 0.1 & 0.8\end{array}$

$\begin{array}{llll}0.3 & 0.1 & 0.8 & \text { NS }\end{array}$

NS 


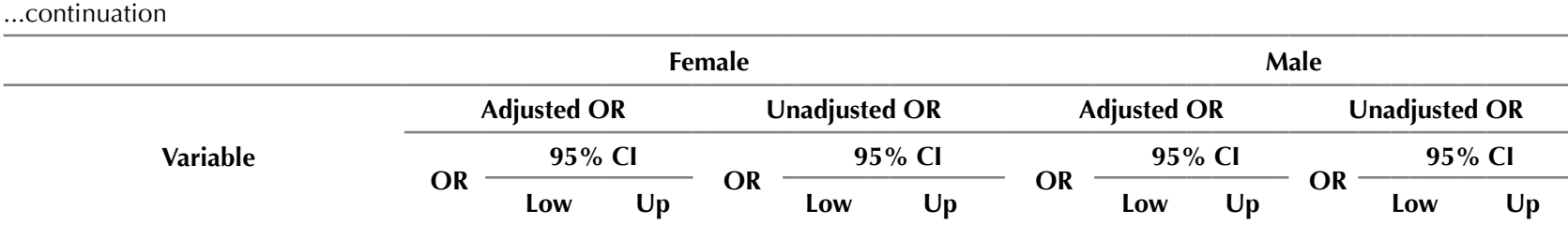

\section{Income in minimum wages}

\begin{tabular}{llll}
$(2,15]$ & 1.0 & & \\
$(1,5,2]$ & 0.8 & 0.5 & 1.3 \\
$(1,1,5]$ & 0.9 & 0.5 & 1.4 \\
$(0,5,1]$ & 0.8 & 0.6 & 1.3 \\
$(0,0,5]$ & 1.1 & 0.7 & 1.8 \\
\hline
\end{tabular}

\begin{tabular}{|c|c|c|}
\hline & 1.0 & \\
\hline 3 & 0.8 & 0.4 \\
\hline 4 & 0.5 & 0.2 \\
\hline & 0.7 & 0.4 \\
\hline $8 \quad$ NS & 1.1 & 0.5 \\
\hline
\end{tabular}

\section{Clinical variables}

Abscess/infection

\begin{tabular}{lrlllllll} 
No & 1.0 & & \multicolumn{7}{c}{1.0} & & \\
Yes & 1.3 & 0.6 & 2.6 & NS & 1.0 & 0.2 & 4.5 & NS
\end{tabular}

Fistula

No $1.0 \quad 1.0$

Yes

$\begin{array}{llllllll}4.1 & 1.4 & 11.8 & \text { NS } & 5.9 & 0.9 & 36.1 & \text { NS }\end{array}$

Anal fissure

\begin{tabular}{llllllllllll} 
No & 1.0 & \multicolumn{1}{c}{1.0} & \multicolumn{1}{c}{1.0} & & & \\
Yes & 2.7 & 1.6 & 4.6 & 2.5 & 1.5 & 4.4 & 0.5 & 0.0 & 4.1 & NS
\end{tabular}

Rectum or anal surgery

\begin{tabular}{lllllllllll} 
No & 1.0 & \multicolumn{1}{c}{1.0} & \multicolumn{9}{c}{1.0} \\
Yes & 2.6 & 1.3 & 5.1 & 2.7 & 1.3 & 5.7 & 2.5 & 0.9 & 6.9 & NS
\end{tabular}

Trauma and injury in the rectum or anus

\begin{tabular}{llllllllllll} 
No & 1.0 & \multicolumn{9}{c}{1.0} & \multicolumn{1}{c}{1.0} \\
Yes & 3.7 & 1.5 & 9.1 & 3.3 & 1.3 & 9.2 & 2.9 & 0.5 & 14.9 & NS
\end{tabular}

\section{Child-birth}

$\begin{array}{llllll}\text { No } & 1.0 & & & & \\ \text { Yes } & 0.9 & 0.741 & 1.2 & \text { NS } & \text { NA }\end{array}$

Injury/tear during childbirth
No
1.0
Yes
I never gave birth
$\begin{array}{lll}0.9 & 0.4 & 1.8\end{array}$
Hysterectomy
No
$\begin{array}{llll}0.904 & 0.4 & 1.8 \quad N S\end{array}$
NA
1.0
Yes
$\begin{array}{llll}0.9 & 0.6 & 1.4 \quad \text { NS }\end{array}$
NA
Rectocele
No
1.0
1.0
Yes
$\begin{array}{lllllll}11.9 & 1.4 & 97.6 & 10.4 & 1.7 & 195.3 & \text { NA }\end{array}$
Rectal prolapse

\begin{tabular}{lrrrrrrrr} 
No & 1.0 & & \multicolumn{9}{c}{1.0} & & \\
Yes & 3.8 & 1.1 & 12.5 & NS & 3.5 & 0.6 & 18.6 & NS \\
\hline
\end{tabular}

continued... 


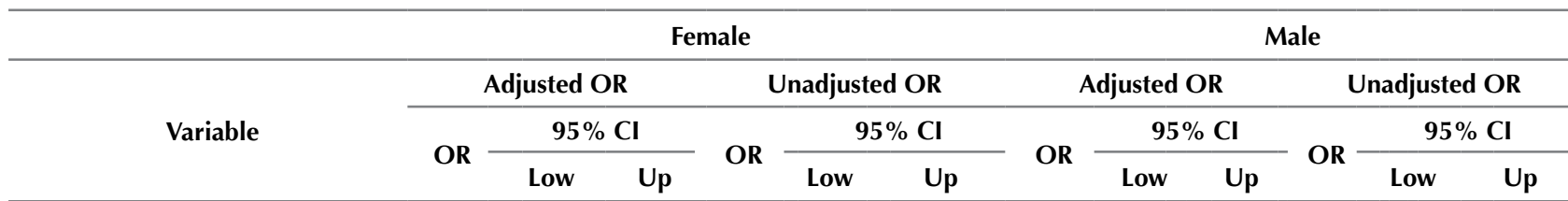

\section{Hemorrhoids}

No

Yes

$$
1.0
$$

$2.0 \quad 1.4$

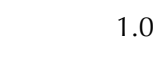

$2.8 \quad 2.0$

.0

Reduced/pushed the hemorrhoids

No, it came back on its own

Yes, I pushed it

No, it has always been out

Radiotherapy

No

Yes

Diabetes Mellitus

No

Yes

Nervous system disorder

No

Yes

Stroke

No

Yes

NS= Not significant. NA $=$ Not applicable. Lo $=$ Lower limit. Up=Upper limit

Adjustable model for female gender: $\mathrm{R}^{2}$ : 0.093; C: 0.632 .

Adjustable model for male gender: $\mathrm{R}^{2}$ : 0.091; C: 0.642 .

The models demonstrated accuracy when obtaining CC values ranging from 0.74 (for the general model) at 0.64 and 0.63 , respectively, for the models in male and female, featuring very good accuracy and good accuracy respectively.

\section{DISCUSSION}

Epidemiological population-based studies are extremely important, since it is from them we can study the occurrence and the mapping of diseases in human populations and define prevention and control strategies, providing thus great contribution to improving the health of populations ${ }^{(15)}$.

In the present study, the prevalence obtained from $\mathrm{CC}$ $(25.2 \%)$ is similar to the rates found in the literature on the subject when using the self-report.

American prospective cohort study, population-based, on chronic constipation in the community, used the questionnaire The Talley Bowel Disease Questionnaire, sent to the participants at different times (1988 to 1994, 2003, 2004, 2008 and 2009). A total of 2853 subjects responded to at least two questionnaires sent in two different periods, showing persistent constipation in 3\%, non-persistent constipation for $21 \%$ and without CC for $76 \%{ }^{(16)}$. In a Brazilian population study ${ }^{(17)}$, with a systematic sample of 2,946 participants (age $\geq 20$ years), the prevalence of self-reported CC (25.6\%) was very similar to that obtained in the present study. Prevalence slightly higher (29.5\% for self-report) the results of both studies was found in a Spanish publication $(\mathrm{N}=349)^{(18)}$.

Some literature reviews have addressed the epidemiology of CC. In a literature review, including 100 studies of population-based cohort, case control studies, cross-sectional and randomized clinical trials, extracted from MEDLINE, EMBASE and classical EMBASE, from 1947 to 2010, using Rome I, II and III criteria or medical diagnosis for defining CC; the authors ${ }^{(5)}$ estimated that the overall prevalence of CC is $14 \%$ for people aged $\geq 15$ years. In other integrative review ${ }^{(4)}$, which included only populationbased studies (2005-2011), in CINAHL, MEDLINE and LILACS databases, the authors found CC prevalence rates ranging from $2.6 \%$ to $26.9 \%$.

The variation in the results of prevalence studies is directly related to the criteria used in the definition of $\mathrm{CC}$, through self-report or Rome Criteria ${ }^{(3)}$.

Several factors were associated with the occurrence of $\mathrm{CC}$ in this study, for the entire sample, for both women and men. The female gender was strongly associated with CC, which is corroborated by numerous other epidemiological studies $^{(8-9,18)}$ and literature reviews ${ }^{(4-7,19-20)}$. CC in women seems to be more common for reasons such as pregnancy and childbirth ${ }^{(4)}$. Women's hormonal changes as well as behavioral factors, history of sexual, physical and emotional abuse, may be related to the digestive system disorders ${ }^{(17)}$. 
Another important demographic variable in the epidemiology of CC is age, which was higher among the elderly ${ }^{(4,19,21-22)}$. Not only the physiological changes of aging such as reduced mobility, health conditions and medications seems to predispose the elderly to the development of $\mathrm{CC}^{(23-24)}$, demanding more accurate diagnosis and specific CC treatment in this population ${ }^{(10,25)}$.

Diseases, changes or previous anorectal surgery also showed statistically significant associations with the presence of $\mathrm{CC}$, in the general sample of constipated as among women. Similarly to those found in a retrospective cohort study ${ }^{(26)}$, the hemorrhoids were a prevalent condition in constipated patients. Associations with fissures, fistulae and traumas were not found in other CC epidemiological population-based studies. Pain and fear result in more difficulties for evacuation. Diseases such as hemorrhoids and anal fissure, when in less advanced stages, can be clinically treated with changes in diet, fiber and fluid intake and proper cleaning of the anal region, which are basic care for the good prognosis as well as the use of topical medications ${ }^{(27)}$.

Associations between CC and stroke, obtained in the three regression models conducted in this study, have also been documented in other publications; in rehabilitation $(22.9 \%)^{(28)}$ or in hospitals $(7 \%)^{(29)}$. One study ${ }^{(30)}$ found CC in $30 \%$ of patients with dementia.

\section{CONTRIBUTIONS AND LIMITATIONS OF THE STUDY}

This research is one of the few epidemiological population-based studies designed with this specific purpose in our country. Thus, besides the contribution of the actual assessment of the prevalence of $\mathrm{CC}$ in Brazilian population sample, some of the association of factors analyzed here (anorectal and nervous system diseases) are not usually tested in the general population, but only in specific groups.

As this is a secondary study, which used a standardized instrument for data collection (The Bowel Function in the
Community Tool), there were no relevant items to the specific evaluation of the $\mathrm{CC}$, such as lifestyle, including food, influencing bowel function.

Given the contributions and limitations of the study, the large variation in the prevalence of $\mathrm{CC}$ found in the general population as well as the gaps identified in the Latin American Consensus on Chronic Constipation, they may be recommendations highlighting the need to conduct further CC epidemiological studies in Latin America and especially in Brazil, in regions other besides the south and southeast. Indeed, the epidemiological characterization of bowel habits of the population, including disorders such as $\mathrm{CC}$, will enable the development of public policies related to early diagnosis of these conditions, as well as the control of the factors associated with them.

We highlight the importance of nurses in the development of epidemiological studies and the formulation of public policies related to gastrointestinal disorders. Nurse is the professional who makes the first contact with the patient through clinical history and physical examination should be able to recognize and raise the factors associated with CC, developing a fundamental role in addressing patients and symptom relief. Thus, the study and knowledge of $\mathrm{CC}$ is essential, knowing its causes and associated factors, by the nursing staff, as well for the early detection of symptoms, proper treatment and prevention of complications, having a positive impact on the control of symptoms and the quality of life of people affected by this condition.

\section{CONCLUSION}

In the present study, the prevalence of $\mathrm{CC}$ in the general population of Londrina city, in the state of Parana, according to self-report, was $25.2 \%$, being $37.2 \%$ for women and $10.2 \%$ for men, showing an increase rate with age advance. Stroke and age were associated with CC in the three statistical models used.

\section{RESUMO}

Objetivo: Estimar a prevalência de constipação intestinal autorreferida e os fatores associados na população geral de uma cidade brasileira. Método: Análise secundária de um estudo epidemiológico, de base populacional e transversal, sobre o hábito intestinal na população brasileira. Foram entrevistados 2.162 indivíduos utilizando-se dois instrumentos: dados sociodemográficos e hábito intestinal na população. Resultados: Obteve-se prevalência de 25,2\% para a constipação autorreferida, sendo 37,2\% para mulheres e $10,2 \%$ entre homens. Acidente Vascular Encefálico e idade avançada apresentaram associação com constipação nos três modelos estatísticos utilizados. Conclusão: A prevalência encontrada mostrou-se similar aos achados na literatura internacional, embora alguns fatores associados aqui obtidos nunca tenham sido investigados.

\section{DESCRITORES}

Constipação Intestinal; Prevalência; Epidemiologia; Enfermagem; Estudos Transversais.

\section{RESUMEN}

Objetivo: Estimar la prevalencia de estreñimiento autorreferido y los factores asociados en la población general de una ciudad brasileña. Método: Análisis secundario de un estudio epidemiológico, de base poblacional y transversal, acerca del hábito intestinal en la población brasileña. Fueron entrevistados 2.162 individuos utilizándose dos instrumentos: datos sociodemográficos y hábito intestinal en la población. Resultados: Se logró prevalencia del 25,2\% para el estreñimiento autorreferido, siendo el 37,2\% para mujeres y el 10,2\% entre los hombres. Accidente Vascular Encefálico y edad avanzada presentaron asociación con constipación en los tres modelos estadísticos utilizados. Conclusión: La prevalencia encontrada se mostró similar a los hallazgos de la literatura internacional, aunque algunos factores asociados aquí obtenidos nunca se hayan investigado.

\section{DESCRIPTORES}

Constipación; Prevalencia; Epidemiología; Enfermería; Estudios Transversales. 


\section{REFERENCES}

1. Bharucha A, Pemberton J, Locke G. American Gastroenterological Association technical review on constipation. Gastroenterology. $2013 ; 144(1): 218-38$

2. Sanchez MI, Bercik P. Epidemiology and burden of chronic constipation. Can J Gastroenterol. 2011;25(Suppl B):11B-15B.

3. Longstreth GF, Thompson WG, Chey WD, Houghton LA, Mearin F, Spiller RC. Functional bowel disorders. Gastroenterology. 2006;130(5):1480-91.

4. Schmidt FMQ, Santos VLCG. Prevalence of constipation in the general adult population: an integrative review. J Wound Ostomy Continence Nurs. 2014;41(1):70-6

5. Suares NC, Ford AC. Prevalence of, and risk factors for, chronic idiopathic constipation in the community: systematic review and metaanalysis. Am J Gastroenterol. 2011;106(9):1582-91.

6. Wasserman MS, Francisconi C, Olden K, Paíz LA, Bustos-Fernández L, Cohen H, Passos MC et al. The Latin-American Consensus on Chronic Constipation. Gastroenterol Hepatol. 2008;31(2):59-74.

7. Peppas G, Alexiou VG, Mourtzoukou E, Falagas ME. Epidemiology of constipation in Europe and Oceania: a systematic review. BMC Gastroenterol. 2008;8:5.

8. Jun DW, Park HY, Lee OY, Lee HL, Yoon BC, Choi HS, et al. A population-based study on bowel habits in a Korean community: prevalence of functional constipation and self-reported constipation. Dig Dis Sci. 2006;51(8):1471-7.

9. Woodward S. Assessment and management of constipation in older people. Nurs Older People. 2012;24(5):21-6.

10. Drossman DA. The functional gastrointestinal disorders and the Rome III process. Gastroenterology. 2006;130(5):1377-90.

11. Chehter L. Constipação intestinal funcional crônica. RBM Rev Bras Med. 2012;69 (12):121-24.

12. Domansky RC. Avaliação do hábito instestinal e fatores de risco para incontinência anal na população geral [tese doutorado]. São Paulo: Escola de Enfermagem, Universidade de São Paulo; 2009.

13. Domansky R, Santos VLCG. Cross cultural adaptation and validation of The Bowel Function in the Community toll to Brazil. Rev Esc Enferm USP [Internet]. 2009 [cited 2014 Oct 13];43(n.spe):1114-29. Available from: http://www.scielo.br/pdf/reeusp/v43nspe/en_a16v43ns.pdf

14. Hosmer DW, Lemeshow S. Applied logistic regression. New York: John Wiley \& Sons; 1989.

15. Bonita R, Beaglehole R, Kjellstrom T. Epidemiologia básica. São Paulo: Santos; 2012.

16. Choung RS, Locke GR, Rey E, Schleck CD, Baum C, Zinsmeister AR, et al. Factors associated with persistant and non-persistant chronic constipation, over 20 years. Clin Gastroenterol Hepatol. 2012;10(5):494-500.

17. Collete VL, Araújo CL, Madruga SW. Prevalência e fatores associados à constipação intestinal: um estudo de base populacional em Pelotas, Rio Grande do Sul, Brasil. Cad Saúde Pública. 2010;26(7):1391-402.

18. Garrigues V, Galvez C, Ortiz V, Ponce M, Nos P, Ponce J. Prevalence of constipation: agreement among several criteria and evaluation of the diagnostic accuracy of qualifying symptoms and self-reported definition in a population-based survey in Spain. Am J Epidemiol. 2004;159(5):520-6.

19. Higgins PD, Johanson JF. Epidemiology of constipation in North America: a systematic review. Am J Gastroenterol. 2004;99(4):750-9.

20. Nellesen D, Yee K, Chawla A, Lewis BE, Carson RT. A systematic review of the economic and humanistic burden of illness in irritable bowel syndrome and chronic constipation. J Manag Care Pharm. 2013;19(09):755-64.

21. Costilla VC, Foxx-Orenstein AE. Constipation: understanding mechanisms and management. Clin Geriatr Med. 2014;30(1):107-15.

22. Ebling B, Gulić S, Jurcić D, Martinac M, Gmajnić R, Bilić A, et al. Demographic, anthropometric and socioeconomic characteristics of functional constipation in Eastern Croatia. Coll Antropol. 2014;38(2):539-46.

23. Gardner A. Constipation: causes, assessment and mana gemer. Nurs Resid Care. 2013;15(6):410-15.

24. McCrea L, Miaskowski C, Stotts N, Macera L, Varma MG. Pathophysiology of constipation in the older adult. World J Gastroenterol. 2008;14(17):2631-8.

25. Roger J. Management of constipation in the community. J Community Nur. 2013;27(2):20-4.

26. Arora G, Mannalithara A, Mithal A, Triadafilopoulos G, Singh G. Concurrent conditions in patients with chronic constipation: a population-based study. PLoS One. 2012;7(10):e42910.

27. Sobrado CW. Tratamento tópico das doenças anorretais. RBM Rev Bras Med. 2013; 71(1):34-42

28. Doshi VS, Say JH, Young SH, Doraisamy P. Complications in stroke patients: a study carried out at the Rehabilitation Medicine Service, Changai General Hospital. Singapore Med J. 2003;44(12):643-52.

29. Ingeman A, Andersen G, Hundborg H, Svendsen M, Johnsen S. Processes of care and medical complications in patients with stroke. Stroke. 2011;42(1):167-72.

30. Stubendorff K, Aarsland D, Minthon L, Londos E. The impact of autonomic dysfunction on survival in patients with dementia with Lewy bodies and Parkinson's disease with dementia. PLoS One. 2012;7(10):454-51. 